\title{
Analysis on Strong Coupling between the WTO and the Internationalization of Chinese Enterprises
}

\author{
Huocan Wang \\ Management School \\ Donghua University \\ Shanghai 200051, China \\ Institute of International Business \\ Shanghai University of International Business and Economics \\ Shanghai 200336, China \\ whc5858@2008.sina.com
}

\begin{abstract}
The purpose of this paper is to explore the unique interaction relationship between the Chinese enterprise internationalization and the WTO multilateral trading system, referred to in this article "the strong coupling relationship". In 13 years since China's accession to the WTO, its trade and FDI have rapidly risen, and the system related to the Chinese enterprise internationalization, such as the trade and investment regimes and intellectual property protection system, have been great change. All of these have fully witnessed that the strong coupling relationship exists between the Chinese enterprise internationalization and the WTO multilateral trading system. For this reason, in the future process of Chinese enterprise internationalization, both Chinese companies and Chinese government should attach great importance to the strong coupling relationship, and thereby this as a strategic starting point, to ensure the strong coupling effect to play more sufficiently by continuing to strengthen the WTO multilateral trading system.
\end{abstract}

Keywords- Strong Coupling; WTO; Chinese Enterprises; Internationalization; Analysis

\section{INTRODUCTION}

China joining the WTO as a big developing country has been 13 years, during this period, the internationalization of Chinese enterprises which is charactered by the rapid development of trade and investment, and the huge changes of trade and investment system has achieved remarkable rise. It fully demonstrated the existence of the strong coupling relationship between the Chinese enterprises internationalization and the WTO. This phenomenon is very rare in other WTO members. In recent more than 10 years after China joined the WTO, however, there are few people in fact that pay attention to and study on the strong coupling relationship between the Chinese enterprise internationalization and the WTO multilateral trading system. This article will explore the special interaction, and then to develop a special index based on the import and export trade and foreign direct investment (OFDI) of China to measure the strong coupling compared with other WTO members. We argues that fully understanding and researching the strong coupling relationship between the Chinese enterprises internationalization and the WTO have important theoretical significance and practical value for the domestic industry, academia and government to understand the Chinese enterprise internationalization and the WTO multilateral trade system itself as well as their interaction relationship.

\section{THE STRONG COUPLING CONCEPT AND ITS EXPRESSION}

In general, the concept of internationalization of enterprises can be defined as that an enterprise engage in international business practice which include the import and export trade and the inward and outward foreign direct investment, and the international management practice which include strategy, organization and personnel under the international game rules of the WTO multilateral trading system. The GATT/WTO multilateral trading system develops from the economical globalization history which is based on the internationalization of enterprises, and also from a "Two-Level Games" model (among WTOgovernment-enterprises). The model clarifies the approach of enterprises engage in multilateral trade negotiation and the WTO affairs. The conclusion is that the current WTO multilateral trading system assures a leveling play, stable commercial expectations and lower transaction expenses in an open, stable and predictable manner.

Coupling is a physics term which has been widely used in electronics, communications, software engineering, mechanical engineering and physics, cosmology. In physics, "coupling" refers to interaction or influence each other between two or more systems or two movement forms. In a nutshell, coupling refers to a measure of the dependent on each other between two or more entities or systems. The strength of the coupling is known as the coupling degree. The more tightly coupled, the greater is the linkage or interaction effect between the systems each other, in another word, the stronger is the coupling effect. In fact, coupling phenomenon also exist in the social system. In this article, the coupling concept in used to express the close interaction between these two social systems, said enterprise internationalization and the multilateral trading system. And the following analysis of this paper will show that in different with the historical coupling relation between the major western countries' enterprises internationalization and the multilateral trading system (from the original GATT to nowadays WTO), the 
coupling relationship between the China's enterprise internationalization and the WTO multilateral trading system presents distinctive characteristics that is just referred to in this article "the strong coupling relationship".

We argued there is a stronger coupling relationship between the WTO multilateral trading system and internationalization of Chinese enterprises with comparison to that of other WTO members. It is rooted in the special historical interaction between China and GATT/WTO multilateral trading system. The stronger coupling relationship between the WTO multilateral trading system and internationalization of Chinese enterprises is embodied not only in the rapid rise of trade and foreign direct investment since China's entry into the WTO, but also in huge transformations of the legal and administrative systems related to internationalization of the Chinese enterprise so as to adaption to the multilateral rules. We will reveal and describe the strong coupling relationship between the Chinese enterprise internationalization and the WTO multilateral trading system from three aspects respectively: trade, investment and institution as follow.

\section{A. The Strong Coupling Reflected in Trade Dimension}

China's accession to the WTO has greatly promoted progress pace of the Chinese enterprise internationalization, and the development of China's open economy. For more than 10 years of China's accession to WTO, China has rapidly risen as a trading power, this is one of the most significant features of the strong coupling between the WTO multilateral trading system and China's enterprise internationalization.

First of all, China's trade liberalization commitments for accession to the WTO did help to its export growth. ${ }^{[1]}$ since accession to the WTO, China's merchandise import and export trade has present a blowout growth (see Fig .1). From 2002 to 2011, China's exports grow from 325.6 billion US\$ to 1.9 trillion, increased of $583 \%$, the average annual growth rate was up to $22.35 \%$. At the same time, the world merchandise exports rose from 6.5 to 18.29 trillion US\$, an increase of $281.56 \%$, the average annual growth of $12.19 \%$. China's export share of the world exports was from $4.3 \%$ in 2001 to $10.4 \%$ in 2011. During the same period, China's imports grow from 295.17 billion US\$ to 1.74 trillion US\$, increased of $590.67 \%$, the average annual growth rate was up to $21.82 \%$. At the same time, the world merchandise imports rose from 6.66 to 18.4 trillion, increased of $276.12 \%$, the average annual growth was up to $11.95 \%$. China's exports and import growth

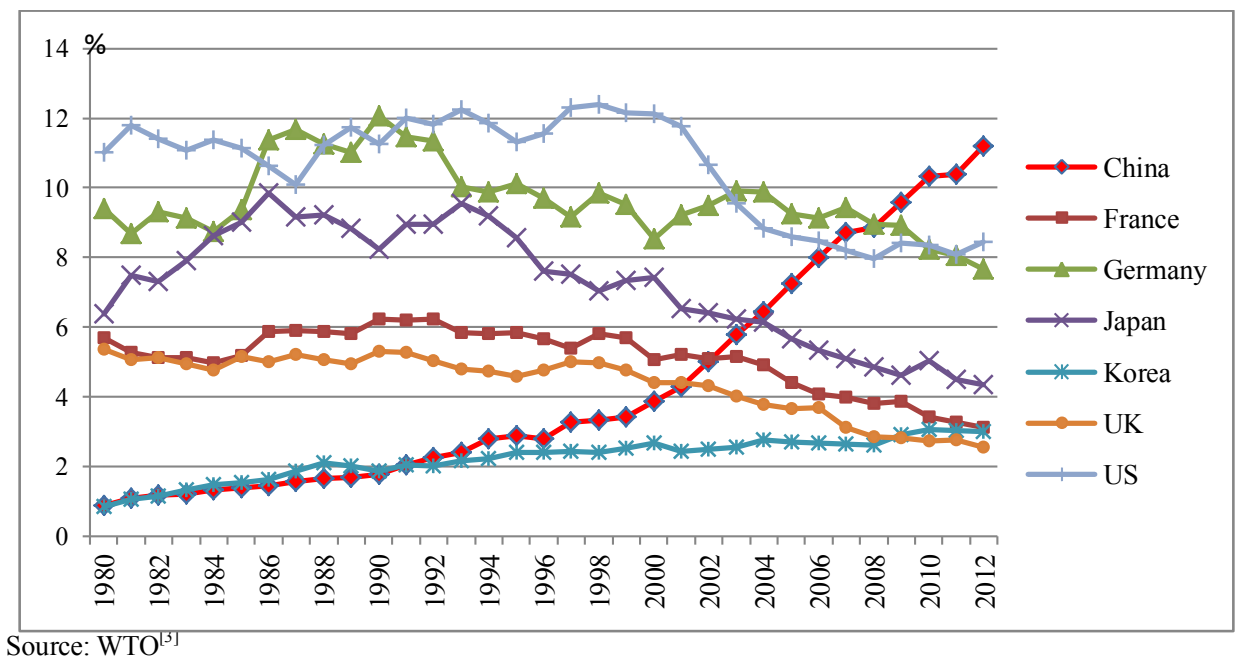

Figure 2. Sharp rising of China's export share in world trade compared with selected trade partners since China's accession to the WTO 
TABLE I. SCI FOR CHINA'S TRADE RELATIVE TO SELECTED WTO MEMBER

\begin{tabular}{|c|c|c|c|c|c|c|}
\hline $\begin{array}{l}\text { Rank } \\
\text { in } \\
2011^{[4]}\end{array}$ & exporters & $\begin{array}{c}\text { average annual } \\
\text { growth rate, } \\
2002-2011 \\
{[\%]}\end{array}$ & $\begin{array}{c}\text { SCI for China's } \\
\text { export } \\
\text { [others }=100]\end{array}$ & importers & $\begin{array}{c}\text { average annual } \\
\text { growth rate, } \\
2002-2011 \\
{[\%]}\end{array}$ & $\begin{array}{c}\text { SCI for China's } \\
\text { import } \\
\text { [others }=100]\end{array}$ \\
\hline 1 & China & 21.64 & - & United States & 7.32 & 298.09 \\
\hline 2 & United States & 8.8 & 245.91 & China & 21.82 & - \\
\hline 3 & Germany & 10.18 & 212.57 & Germany & 11.01 & 198.18 \\
\hline 4 & Japan & 7.86 & 275.32 & Japan & 10.9 & 200.18 \\
\hline 5 & Netherlands & 11.82 & 183.08 & France & 9.08 & 240.31 \\
\hline 6 & France & 6.74 & 321.07 & United Kingdom & 7.08 & 308.19 \\
\hline 7 & Korea, Republic of & 14.63 & 147.92 & Netherlands & 11.81 & 184.76 \\
\hline 8 & Italy & 8.34 & 259.47 & Italy & 9.49 & 229.93 \\
\hline 9 & Russian Federation & 19.22 & 112.59 & Korea, Republic of & 14.74 & 148.03 \\
\hline 10 & Belgium & 9.17 & 235.99 & Hong Kong, China & 10.5 & 207.81 \\
\hline \multirow{2}{*}{\multicolumn{2}{|c|}{$\begin{array}{c}\text { World } \\
\text { Developing economies }\end{array}$}} & 12.19 & 177.52 & & 11.95 & 182.59 \\
\hline & & 15.98 & 135.42 & & 16.01 & 136.29 \\
\hline \multicolumn{2}{|c|}{ Transition economies } & 19.79 & 109.35 & & 18.89 & 115.51 \\
\hline \multicolumn{2}{|c|}{ Developed economies } & 9.44 & 229.24 & & 9.54 & 228.72 \\
\hline
\end{tabular}

the world's top ten in 2011. It is shown that China's SCI based on import and export are all stronger than that of other top nine members. For example, the China's SCI of export range from low 112.59 of Russian Federation to high 321.07 of France.

\section{B. The Strong Coupling Reflected in OFDI Flow \\ Dimension}

Since China's accession to WTO, while China rapidly became a trading power, it also quickly became a main power of inward and outward FDI (see Fig .3). During 2001 to 2012, China's IFDI flow increased fast from 49.67 to 113.29 billion US\$, increased by 1.28 times. At the same time, China's OFDI flow increased fast from 6.9 to 77.22 billion US\$(non-financial OFDI), increased by
10.12 times. The average annual flow of China's IFDI in 2002-2011 reached $90.59 \mathrm{~b} \$$, only behind the US and UK. By 2012, China has become the world's fifth largest investor of OFDI.

For FDI dimension, the strong coupling relationship between the Chinese enterprises internationalization and the WTO is the most prominent in China's OFDI flow during the more than 10 years after China's accession to WTO (see table II). It is also shown that China's SCI based on OFDI flow is stronger than that of other top 20 members with range from low 118.35 of Russian Federation to high 2455.5 of France. It means of China's annual growth rate of OFDI flow is very higher than other

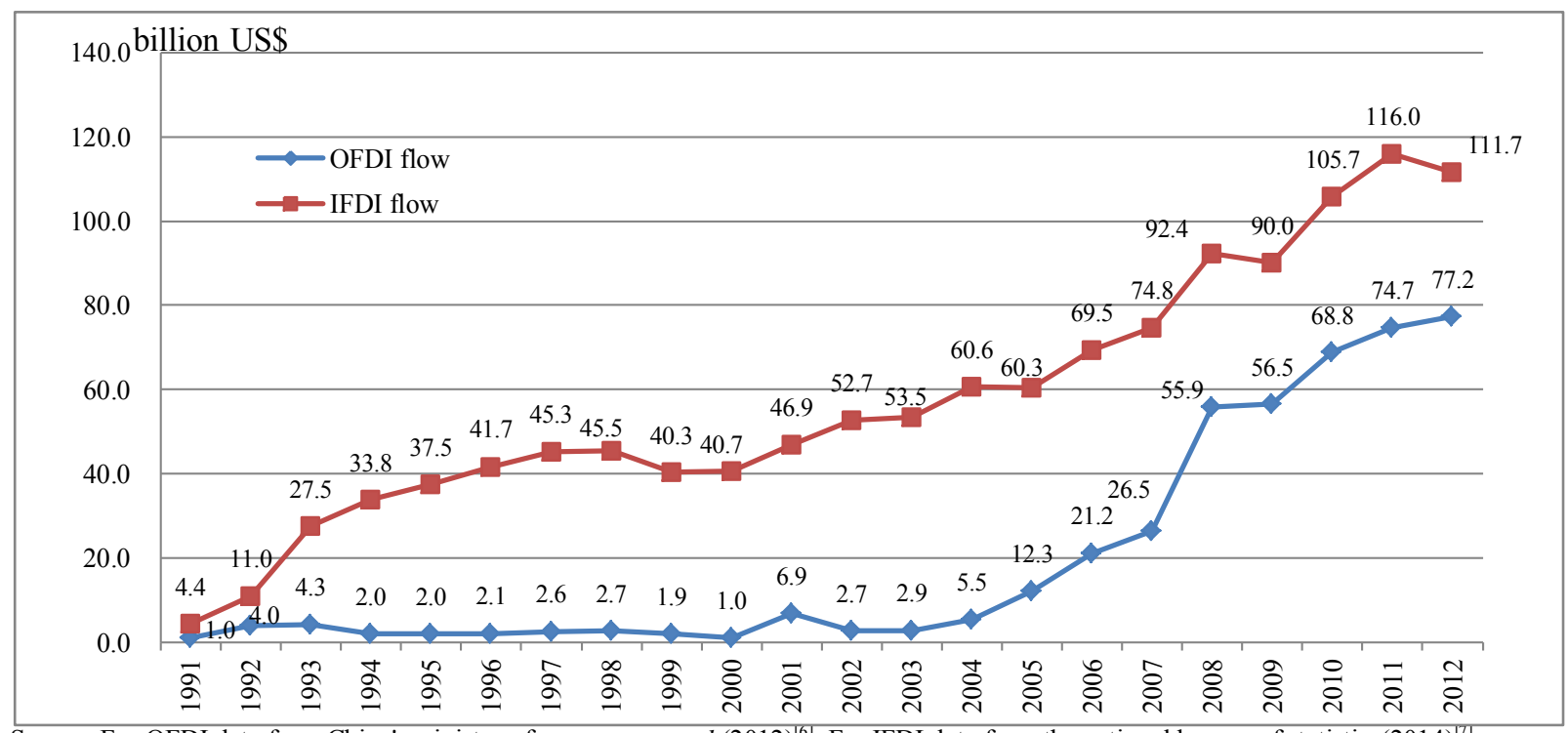

Source: For OFDI data from China's ministry of commerce, et al.(2012) ${ }^{[0]}$; For IFDI data from the national bureau of statistics(2014) ${ }^{[/]}$.

Figure 3. IFDI \& OFDI flows of China in 1991-2012 
TABLE II. SCI FOR CHINA'S OFDI FLOW RELATIVE TO SELECTED WTO MEMBERS

\begin{tabular}{|c|c|c|c|}
\hline & \begin{tabular}{|c|} 
average annual \\
OFDI flow, \\
$2002-11$ \\
[billion US\$]
\end{tabular} & $\begin{array}{c}\text { average annual } \\
\text { growth rate, } \\
2002-11 \\
{[\%]}\end{array}$ & $\begin{array}{c}\text { SCI for } \\
\text { China's OFDI } \\
\text { flow } \\
\text { [others }=100]\end{array}$ \\
\hline China & 32.67 & 45.73 & 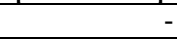 \\
\hline US & 246.86 & 12.73 & 359.31 \\
\hline UK & 107.04 & 8.19 & 558.24 \\
\hline France & 93.66 & 1.86 & 2455.50 \\
\hline Germany & 72.66 & 11.91 & 383.91 \\
\hline Japan & 62.82 & 14.31 & 319.49 \\
\hline Belgium & 60.30 & 23.57 & 193.99 \\
\hline Hong Kong, China & 52.45 & 21.80 & 209.74 \\
\hline Canada & 43.49 & 7.15 & 639.50 \\
\hline Switzerland & 42.62 & 21.50 & 212.74 \\
\hline Italy & 38.18 & 18.81 & 243.16 \\
\hline Russia & 33.92 & 38.64 & 118.35 \\
\hline Sweden & 25.18 & 11.47 & 398.83 \\
\hline Austria & 15.87 & 17.56 & 260.49 \\
\hline Korea, Rep. of & 14.83 & 28.55 & 160.15 \\
\hline Australia & 13.91 & 7.43 & 615.73 \\
\hline $\begin{array}{c}\text { China, Taiwan } \\
\text { Province of }\end{array}$ & 8.28 & 11.26 & 406.08 \\
\hline Malaysia & 7.71 & 26.00 & 175.87 \\
\hline Mexico & 6.39 & 33.67 & 135.81 \\
\hline World & 1297.73 & 13.64 & 335.26 \\
\hline Developed economies & 1021.98 & 10.56 & 433.05 \\
\hline Developing economies & 238.25 & 27.66 & 165.33 \\
\hline
\end{tabular}

\section{Source: UNCTADstat ${ }^{[8]}$}

main members, although in terms of the average annual OFDI flow during 2002-2011, China's average flow is relative smaller up to 32.67 billion US\$ per year, ranked in $12^{\text {th }}$ after Russian Federation.

\section{The Strong Coupling Reflected in Institutional Dimension}

The strong coupling between Chinese enterprises internationalization and the WTO multilateral trading system also reflect in institutional dimension. First of all, in a very short period of time, the China central and local governments cleaned up, included in abolishing, amending and reformulating, tens of thousands of pieces of laws, regulations, policies and measures related to Chinese enterprise internationalization that were inconsistent with WTO rules and China's WTO accession commitments. The number of laws and regulations that were cleaned up or revised was more than 3000 at the central level and about 190000 at local governmental level.

Second, the WTO basic principles such as transparency and openness have promoted China's legislative and governmental affairs public ${ }^{[9]}$. Again, the WTO has pushed China's transition to a market economy, although it cannot be simply attributed to the pressure from accession to the WTO, the accession undoubtedly promoted the transformation process to market economy ${ }^{[10]}$. In the end, the WTO has influenced on the concept of internationalization, the global view and the strategic consciousness of Chinese enterprise. For example, Some basic principles of the WTO multilateral trading system, such as non-discrimination, transparency, rulebased, mutual benefit, fair competition and so on, have greatly influenced the Chinese enterprises' consciousness of rule of law and fair competition, even have pushed them to change their strategies of participation to international competition. Of course, the internationalization of Chinese enterprises will reshape global competition. ${ }^{[11]}$

\section{CONCLUSSIONS}

China's trade and OFDI achievements have shown in more than a decade since China's entry into WTO that there is a strong coupling relationship between China's enterprise internationalization and the WTO multilateral trading system which is different from other WTO members. From a strategic consideration, therefore, in the future process of the internationalization of China's enterprises, China should firmly continue to hold high the multilateralism flags, maintain and promote the WTO multilateral trading system, so as to ensure the strong coupling effect between Chinese enterprise internationalization and the WTO multilateral trading system to play more fully.

\section{REFERENCES}

[1] Ling Feng, Zhiyuan Li, and Deborah L. Swenson, The Connection between Imported Intermediate Inputs and Exports: Evidence from Chinese Firms, NBER Working Paper No. 18260, July 2012. http://www.nber.org/papers/w18260.pdf.

[2] The national bureau of statistics: China statistical yearbook 2012, Beijing: China Statistics Press, 2013.

[3] WTO: International Trade Statistics $(2003,2010,2012)$

[4] WTO: Trade Growth to Slow in 2012 after Strong Deceleration in 2011, Press/658, 12 April 2012. WTO website[2012-04-12]. http://www.wto.org/ english/news_e/pres12_e/pr658_e.htm.

[5] WTO: WTO statistics database. Available at: $\mathrm{http} / /$ stat.wto.org/StatisticalProgram/WSDBStatProgramH ome.asp $x$ ? Language $=\mathrm{E}$.

[6] China's ministry of commerce, the national bureau of statistics, and SAFE: 2011 statistics bulletin of the China's outward foreign direct investment, Beijing: China Statistics Press, 2012, p.6.

[7] The national bureau of statistics: China statistical yearbook 2013, Beijing: China Statistics Press, 2014.

[8] UNCTAD: UNCTADstat, Information on http://unctadstat.unctad.org/wds/ReportFolders/reportFolde rs.aspx?sCS_ChosenLang=en, 2014-10-20.

[9] John H. Jackson, Sovereignty, the WTO, and Changing Fundamentals of International Law, Cambridge University Press, 2006.

[10] Nan Lu and Hongjun Gao, "China and the WTO: Retrospect and prospect of global perspective," Journal of Tsinghua University (Philosophy and Social Sciences Version), no.6, 2012, pp.5-17.

[11] Ilan Alon, Julian Chang, Marc Fetscherin, Christoph Lattemann and John R. McIntyre, China Rules: Globalization and Political Transformation, Palgrave Macmillan, September 2009. 